\title{
Calcium phosphate preservation of faecal bacterial negative moulds in hyaena coprolites
}

\author{
María Dolores Pesquero, Virginia Souza-Egipsy, Luis Alcalá, Carmen Ascaso, and Yolanda
} Fernández-Jalvo

Acta Palaeontologica Polonica 59 (4), 2014: 997-1005 doi: http://dx.doi.org/10.4202/app.2012.0067

The vertebrate fossil locality of La Roma 2, Spain (Upper Miocene, Late Vallesian, MN10) is characterised by a high abundance of mammalian coprolites, which provide direct clues to the diets and habitats of the organisms that produced them. X-ray diffraction analysis showed a sample of hyaena (cf. Lycyaena chaeretis) coprolites to be mostly composed of calcium phosphate. Ultrastructural SEM and TEM studies revealed three successive phases of preservation, including an initial phase of mineralisation that produced microspherulites within a very fine-grained cement. This indicates that most of the calcium phosphate present in the coprolites precipitated rapidly, which in turn facilitated the formation of negative moulds of faecal bacteria within the coprolite matrix.

Key words: Bacteria, hyaena coprolites, structural preservation, taphonomy, Miocene, Spain.

María Dolores Pesquero [pesquero@fundaciondinopolis.org], Fundación Conjunto Paleontológico de Teruel-Dinópolis, 44002 Teruel, Spain and Museo Nacional de Ciencias Naturales, MNCN-CSIC, 28006 Madrid, Spain; Virginia Souza-Egipsy [virginia.souza@ica.csic.es], Instituto Ciencias Agrarias, ICACSIC, 28006 Madrid, Spain; Luis Alcalá [alcala@ fundaciondinopolis.org ], Fundación Conjunto Paleontológico de Teruel-Dinópolis, 44002 Teruel, Spain; Carmen Ascaso [ascaso@ccma.csic.es] and Yolanda Fernández-Jalvo [yfj@mncn.csic.es], Museo Nacional de Ciencias Naturales, MNCN-CSIC, 28006 Madrid, Spain.

This is an open-access article distributed under the terms of the Creative Commons Attribution License (for details please see creativecommons.org), which permits unrestricted use, distribution, and reproduction in any medium, provided the original author and source are credited. 
Fof Full text $(958.7 \mathrm{kB})$ 